\title{
A transport strategy for Portugal
}

\author{
N. M. Gomes Rocha ${ }^{1,2}$ \\ ${ }^{I}$ Department of Civil Engineering, Faculty of Engineering, \\ University of Porto, Portugal \\ ${ }^{2}$ PROEC-Projectos, Estudos e Construções Lda., Portugal
}

\begin{abstract}
During the 2009 Portuguese general election, transport infrastructure construction was a decisive theme. Where should a new international airport be built? What new highways are reasonable? Should Portugal be connected with European high speed train network? Every political opinion-maker has a perception about these issues. Discussion was even inflated because of global and internal economical recession. Previously established decisions were modified or questioned. For similar problems it is possible to find numerous solutions. Each study is considered as a political answer rather than technical. Transport infrastructures are analysed as a potential economical development model redefinition. Until now, an internal mobility paradigm for passengers and logistics is sustained in road transportation. Despite all kind of actions, an involving and unanimous solution seems impossible to be reached. With this paper we are going to analyse two main questions (a new international airport and a high speed train network) and its impacts on the Portuguese transport strategy. We will list intentions for transport and mobility policy contained in elected parties political programs, with no exclusions concerning the author's political considerations. The list includes proposals for rail, air, road and maritime transport. Two main questions are going to be analysed according to the international state of art, European and National strategic guidelines and validated data evaluation. This information will be used to develop a theoretical model for transport in Portugal. A list of proposals will precede the conclusion.
\end{abstract}

Keywords: transport strategy, transport policy, rail transport, air transport, maritime transport, road transport, anatomic transport network. 


\section{Introduction}

Portugal has a $92,389 \mathrm{~km}^{2}$ area representing almost $16 \%$ of the Iberian Peninsula. With more than $750 \mathrm{~km}$ of coastline, Portugal, as explained by Sieber [1], created the first figure of a global trade world. During $15^{\text {th }}$ century, main maritime transport was controlled by Iberian countries. As this influence reduced a new challenge raised. What should the Portuguese strategic position be on international transport?

With an average length of $700 \mathrm{~km}$ and an average width of $175 \mathrm{~km}$, the Portuguese population is concentrated in a $30 \mathrm{~km}$ wide corridor next to the sea. This concentration has a direct impact on every aspect of daily life, especially in terms of mobility.

Transport infrastructures include air, rail, maritime and road transportation. There are one international airport, two medium-size regional airports, six small local airports and other smaller infrastructures. The rail infrastructure is based on two Pendular (medium-high speed trains) North-South crossing-lines, four main regional East-West crossing lines, and two main cities urban rail services. The maritime infrastructure is composed of seven main ports, five only for cargo and two for cargo and passengers, and fourteen smaller infrastructures. The road infrastructure is sustained by more than $2000 \mathrm{~km}$ of highways and numerous $\mathrm{km}$ of national roads.

According to the latest data of GPERI [2] (the National Strategic Planning Department), the number of plane movements is higher than 280,000 with more than 27 million passengers, reflecting a stable growing historic. In cargo, almost 143 tonnes are registered, with a more concentrated distribution compared to passengers.

The light urban rail infrastructure, with a stable historic, is responsible for more than 115.5 million passengers/semester, representing almost 1.5 more passengers than heavy rail infrastructure (77.5 million) presenting a fluctuating historic. Cargo transport is reflecting economical deflection with a reduction to 4 million tonnes, based on GPERI [3].

Maritime transport, as reported by GPERI [4], was presenting a stable growth, in 2008 , in terms of number of vessels, more than 15,000 , representing almost $60 \%$ of international cargo transfer.

Despite its relevance there is no information about road transport at a national level, although some studies considered that represents more than $65 \%$ of all displacements, with more than $70 \%$ of it in private modes.

During the 2009 Portuguese general election, the transport infrastructure was one of the most discussed themes. Do we need a new international airport? Should Portugal be connected to the European high speed train network? What new highways are reasonable? This discussion was inflated because of economical, international and internal recession. Impacts on economy, employment, investments sustainability and project finance were, in most cases, discussed by political opinion makers with a reduced technical approach.

In this paper were going to analyse the new international airport and high speed train network projects. A list of political proposals for a transport policy 
will be presented in section 2. This list includes all elected parties' proposals for air, rail, maritime and road transportation. This will be followed, in section 3 , by an analysis of the new international airport and high speed train network main questions. This analysis will be focused on four aspects: the international state of the art, European and National strategic guidelines and actualized data evaluation. The conclusion, in section 6 , is going to be preceded by a presentation of a theoretical model for transport in Portugal, section 4, and a list of proposals in section 5 .

\section{Proposals for transport}

\subsection{Political principles}

Although it is the most proclaimed strategy, an integrated transport policy and planning is almost never implemented. Integrated policy and planning is, on one hand, presented as a solution to urban transport networks by interconnecting timetables and services coordinated by Metropolitan Transport Authorities, and on the other hand, by articulating transport, security and habitation policies. This is substantiated in specific measures like implementing house renting markets in city centre to reduce commuting and social exclusion, conditioning house developments to public transport connection, creating urban bike services and the implementation of information technologies to create carpooling services or collective taxis. Some of these measures are also studied by Church et al. [5].

Most principles are associated with ideological perceptions. One side support a higher presence of the State in transport companies; in the same proportion the other side support complete privatization. This is also visible in the user-payer concept; indispensable for some while others propose free transport services. This fact has different impacts on the perception about public transportation subventions. Some of these relations were also analysed by Deakin [6].

Common points include a change of mobility paradigm from individual to collective transport, however strategies are different. Creating an intermodal network, charging rings or public transport lanes are some proposals. Another common ground is investing in renewable energies in order to increase efficiency and reduce environmental impact.

\subsection{Air transportation}

International airport construction perceptions range from essential to delayed modular construction and delayed to the result of national airports management company privatization.

Other proposals are the integrated management of different airports, the modernization and opening of military and other smaller infrastructures to commercial service and the development of a strategic profile of each airport according to region of implementation characteristics. 


\subsection{Rail transportation}

High speed train lines' construction has a completely diverse opinion. From complete suspension to limitation to the European connection and to 3 lines construction; everything in between was proposed.

Rail transportation is valued as essential to urban and interurban mobility. A connection between main cities and the development of surface light rail networks are some proposals.

Common proposals include transference to the European Gauge and rolling stock buying. Increasing cargo rail transport is also consensual as essential to achieve market sustainability.

\subsection{Maritime transportation}

Maritime transportation proposals are focused on logistical chain. Rail connection between main ports and services/goods consuming centres is the most significant measure, with a focus not only on the internal market but also in Spain. Changes in ports' management, sea highways' concept fomentation and public maritime merchant company creation are some proposals.

\subsection{Road transportation}

New highways concessions, according to some political programs, should be reanalysed in terms of moderation and economical sustainability. Investment should be forward to national roads improvement. However, some political programs, propose construction in three main axes, namely two located from the west/east and one in the countryside from north/south.

\section{Two axes of a transport strategy}

\subsection{New international airport}

The first studies about a new airport started in 1969. Final localization changed at least four times among almost fifteen potential locations. Political affirmations, lately denied/changed, were turned into public jokes because of the level of certainty in the first statement. Between 1997 and 2005 almost 70 studies about the theme were produced.

Table 1: $\quad$ Efficiency figures in European airports.

\begin{tabular}{|c|c|c|c|c|c|}
\hline Airport & $\begin{array}{c}\text { Annual Passengers } \\
\text { Volume }\end{array}$ & $\begin{array}{c}\text { Check-in } \\
\text { Desks }\end{array}$ & APV/CD & $\begin{array}{c}\text { Aircraft } \\
\text { Stands }\end{array}$ & APV/AS \\
\hline Heathrow & $65.7 \mathrm{M}$ & 526 & 124,905 & 241 & 272,614 \\
\hline Lisbon & $13.6 \mathrm{M}$ & 127 & 107,086 & 41 & 331,707 \\
\hline Porto & $4.5 \mathrm{M}$ & 60 & 75,000 & 14 & 321,429 \\
\hline
\end{tabular}


The current international airport is located in Lisbon city centre, with no potential for expansion. According to most studies, this infrastructure will start losing efficiency in six to eight years.

The previous table presents Lisbon airport's airplane parking limitations. With two passengers terminals this airport is dividing opinions. On one side is the commodity of having an international airport in the city centre and on the other side is the noise and other environmental impacts.

The average linear distance between main international airports in Europe and city centres is $18 \mathrm{~km}$. The longest linear distance is $40 \mathrm{~km}$ and the smallest is Lisbon $(5 \mathrm{~km})$. Some of these airports are associated with other airports near to the city centre however these solutions have a strategic option behind them. As explained by Wijnen et al. [7] normally in these solutions, the international airport is located in the city's outskirts and the national/internal airport is located in the city centre, in order to minimize the time cost compared to rail services usually used to internal displacements. This was considered as a possibility for Portugal, however this solution is refutable. Lisbon's international airport would stay inside and national/internal airport would be built outside. This possibility becomes ineffective especially if the intention of building high speed train lines between Portugal's main cities were considered.

Another point in discussion is the airport-city centre connection transportation infrastructures. Today, access is only possible by road. In most international airports there are rail connections and in some of them those are high speed train connections.

Modular construction of such infrastructure is a false question mainly because it is always modular. The main issue is actually to guarantee expansion, a situation that is physically impossible in the current infrastructure.

A cost/benefit analysis is also an interesting question. To establish a consensus a study was ordered for the Civil Engineering National Laboratory (LNEC) to compare two locations. One is a long established location and another is a recent proposal. LNEC study [8] considered seven factors: safety, efficiency and the capacity of aerial traffic operations; natural resources sustainability and risks; nature conservation and biodiversity; land transport infrastructures and accessibilities; land organization; economical and social development; and financial evaluation. According to the announced decision, the recently presented winning location won in four against three factors, namely safety, efficiency and capacity of aerial traffic operations; natural resources sustainability and risks; social and economical development; and financial evaluation. The second choice won in nature conservation and biodiversity; land transport infrastructures and accessibilities; and land organization. However, in a closer look of the final report it is possible to verify that is not so clear.

In a regression analysis of some factors, it is possible to reach some conclusions. For factor 1, superficiality of existing studies could reverse analysis. For location A, a maximum of 100 aircraft movements/hour is expected, while for location B it would be 70 aircraft movements/hour. 
Table 2: $\quad$ LNEC conclusions.

\begin{tabular}{|c|c|c|}
\hline Location & $\mathbf{A}$ & B \\
\hline Factor 1 & + & - \\
\hline Safety & In both locations it $\mathrm{i}$ & to guarantee accurate safety levels \\
\hline Efficiency & \multirow{2}{*}{\multicolumn{2}{|c|}{$\begin{array}{l}\text { However, the winning location studies should be deepened, the } \\
\text { existing data indicates that is the most favourable }\end{array}$}} \\
\hline CATO & & \\
\hline Factor 2 & + & D \\
\hline $\begin{array}{l}\text { Superficial } \\
\text { waters }\end{array}$ & \multicolumn{2}{|c|}{$\begin{array}{l}\text { Reorganization of water lines in location B is much more complex } \\
\text { than A, so the costs of the interventions are higher }\end{array}$} \\
\hline $\begin{array}{l}\text { Subterranean } \\
\text { waters }\end{array}$ & \multicolumn{2}{|c|}{$\begin{array}{c}\text { However, the information is uncertain for both locations, } \\
\text { characteristics and vulnerability are similar }\end{array}$} \\
\hline Geotechnical & \multicolumn{2}{|c|}{$\begin{array}{l}\text { Existing situation is in disfavour of location B, however, terrestrial } \\
\text { accessibilities construction in location A could lead to a change in } \\
\text { preconceptions }\end{array}$} \\
\hline Factor 3 & - & + \\
\hline $\begin{array}{c}\text { Natural } \\
\text { conservation }\end{array}$ & \multirow{2}{*}{\multicolumn{2}{|c|}{$\begin{array}{c}\text { Infrastructures like airports have profound impacts on the territory; } \\
\text { however the ecological characteristics of locations are different. } \\
\text { Location B has small and fragmented areas while in location A } \\
\text { they are vast and with high value. }\end{array}$}} \\
\hline Biodiversity & & \\
\hline Factor 4 & - & + \\
\hline LTI & \multirow{2}{*}{\multicolumn{2}{|c|}{$\begin{array}{l}\text { Location B presents lower management costs, externalities, time } \\
\text { cost and better access to } 2 / 3 \text { of the country, while location } A \\
\text { presents in a new bridge construction scenario better access to } 1 / 3 \\
\text { of the country. }\end{array}$}} \\
\hline Accessibilities & & \\
\hline Factor 5 & - & + \\
\hline Demography & \multicolumn{2}{|c|}{$\begin{array}{c}\text { Location B presents a more favourable population distribution and } \\
\text { dynamics, while location A could generate a higher territorial } \\
\text { equilibrium. }\end{array}$} \\
\hline $\begin{array}{l}\text { Soil Use and } \\
\text { Occupation }\end{array}$ & \multicolumn{2}{|c|}{$\begin{array}{l}\text { In both locations there is the risk of diffuse urbanization, with } \\
\text { worst impacts in location A because of environmental impacts. }\end{array}$} \\
\hline $\begin{array}{l}\text { Economical and } \\
\text { companies } \\
\text { dynamics }\end{array}$ & \multicolumn{2}{|c|}{$\begin{array}{l}\text { There are reduced differences between locations, because of } \\
\text { territorial superimposition. In both locations the new airport will } \\
\text { generate positive impacts in productive tissue reconversion. }\end{array}$} \\
\hline Factor 6 & + & - \\
\hline $\begin{array}{c}\text { Economical and } \\
\text { social } \\
\text { development }\end{array}$ & \multirow{2}{*}{\multicolumn{2}{|c|}{$\begin{array}{l}\text { Scenario } 1 \text { - Portugal has global hub and a platform of services } \\
\text { and innovation, Scenario } 2 \text { - Portugal has a space of leisure, and } \\
\text { entrance gate of Europe from Brazil. Location A is more } \\
\text { favourable in achieving scenario } 1 \text { based on the optimization of } \\
\text { economical and financial conditions of the project and } \\
\text { approximation of the strategic positioning with higher competition } \\
\text { capacity }\end{array}$}} \\
\hline $\begin{array}{l}\text { Opportunities and } \\
\text { risks }\end{array}$ & & \\
\hline Factor 7 & + & \\
\hline Total investment & $\begin{array}{r}4926.6 \mathrm{M} \\
\end{array}$ & $5191.2 \mathrm{M}$ \\
\hline Analysis & \multicolumn{2}{|c|}{$\begin{array}{c}\text { Considering location B numerous studies, the level of certainty is } \\
\text { higher in this location; however location A cost optimization could } \\
\text { even increase this differential. }\end{array}$} \\
\hline
\end{tabular}


Table 3: 2008 Aircraft movements/hour.

\begin{tabular}{|c|c|c|}
\hline Airport & Annual aircraft movements & Average aircraft movements/hour \\
\hline Lisbon & 140,016 & 16 \\
\hline Porto & 56,095 & 7 \\
\hline
\end{tabular}

With a $2.8 \%$ annual average growth, seven times higher than the 2007/2008 Lisbon airport variation and $12 \%$ higher than national growth average $(2.5 \%)$, in operating year 50, aircraft movements/hour would only reach 62 .

The factor 6 valorisation of Scenario 1 is a political/strategic option with no special technical support. In fact, Portugal is closer to scenario 2. In the study it is not explicit what the most favourable location for scenario 2 is. Recent economical/financial events make both scenarios vulnerability and stability analysis questionable. Actually, the services sector stability in comparison to the transformed or natural goods commercialization sector, especially considering the Brazilian economical growth in an economical recession, apparently makes scenario 2 more desirable.

The last question is about factors 4 and 7. The LNEC study does not quantify a financial differential in management costs of accessibilities and land transport infrastructures between locations.

In table 4 the case of an underground line construction in a European city is presented. Annual management costs represent $10 \%$ of total investment in infrastructure life time end.

Table 4: Annual management cost/total investment.

\begin{tabular}{|c|c|c|}
\hline & Value & $\begin{array}{c}\text { Percentage of annual management } \\
\text { cost in Total Investment }\end{array}$ \\
\hline Construction costs & $1062 \mathrm{M}$ & \\
\hline Financial Costs & $531 \mathrm{M}$ & $1.5 \%$ \\
\hline $\begin{array}{c}\text { Annual management costs } \\
\text { in year 1 }\end{array}$ & $23.90 \mathrm{M}$ & $5 \%$ \\
\hline $\begin{array}{c}\text { Annual management costs } \\
\text { at year 25 }\end{array}$ & $79.65 \mathrm{M}$ \\
\hline $\begin{array}{c}\text { Annual management costs } \\
\text { at year 50 }\end{array}$ & $159.3 \mathrm{M}$ & $10 \%$ \\
\hline
\end{tabular}

Airport construction direct costs are $3200 \mathrm{M}$ for location A and 3500M for location B. Considering an average differential, distributed during the infrastructure's life, of 3\% in management costs of land transport infrastructures and accessibilities between locations and assuming that direct management costs of the airport infrastructure is similar in both locations, the final cost, at infrastructure life time end, for location A and B, will be similar, as presented in table 5 . 
Table 5: $\quad$ Final costs comparison.

\begin{tabular}{|c|c|c|c|c|}
\hline Location & $\begin{array}{c}\text { Total } \\
\text { Investment }\end{array}$ & $\begin{array}{c}\text { Other } \\
\text { Costs }\end{array}$ & $\begin{array}{c}\text { Management Costs } \\
\text { of LTI }\end{array}$ & $\begin{array}{c}\text { Partial Final } \\
\text { Cost }\end{array}$ \\
\hline $\mathrm{A}$ & $4926.6 \mathrm{M}$ & $1726.6 \mathrm{M}$ & $4834.48 \mathrm{M}$ & $9742.74 \mathrm{M}$ \\
\hline $\mathrm{B}$ & $5191.2 \mathrm{M}$ & $1691.2 \mathrm{M}$ & $4545.1 \mathrm{M}$ & $9736.3 \mathrm{M}$ \\
\hline
\end{tabular}

\subsection{High speed train lines}

In the European Union (EU) White Book for Transports Policy [9] there is a special focus on a European high-speed train network development. This means that Portugal will have to build at least the Portuguese side of the Madrid/Lisbon connection. However, another two axes are in development (Lisbon/Porto and Porto/Vigo).

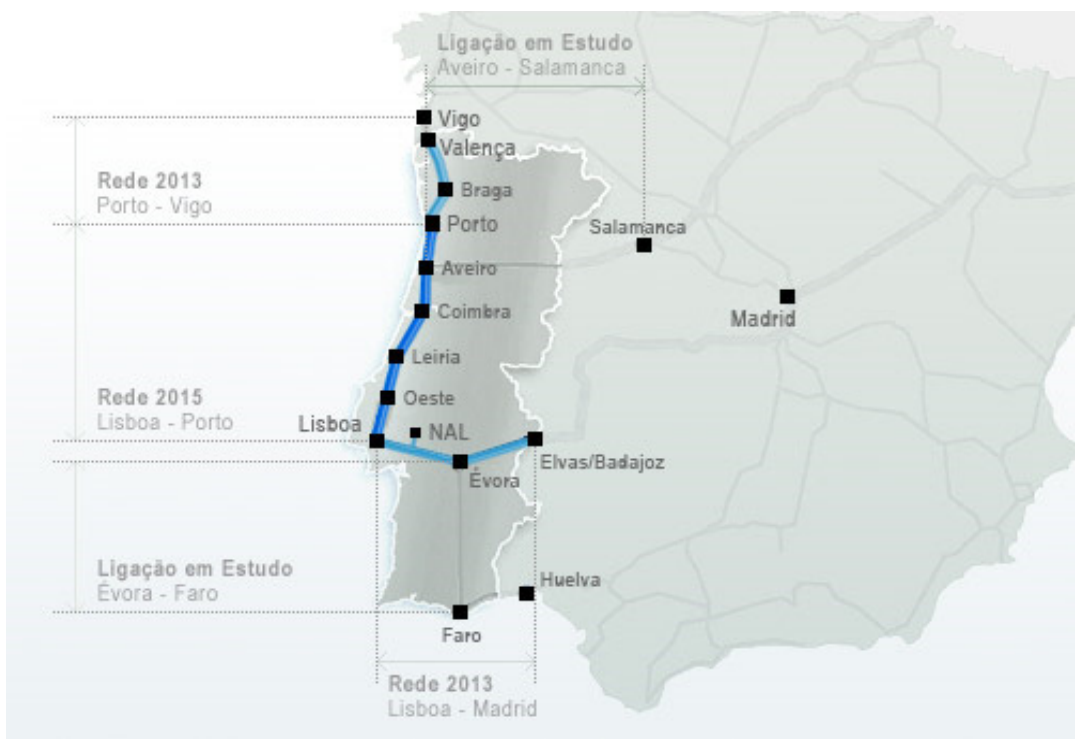

Figure 1: $\quad$ Portuguese high speed train network (2013-2015).

The main question about this project is cost/benefit analysis (CBA). This becomes more important when two companies, responsible for the existing network management, have more than $5500 \mathrm{M}$ of debt. Heavy rail transport is responsible for more than $150 \mathrm{M}$ passengers, however only $11 \%$ (17MPax) is inter-urban transport.

The CBA approach should consider four points: Alternatives; Type of Impacts; Discounting and Internal Rate of Return; and Sensitivity and Risk analysis. Crucial analysis is defining demand influencing factors. Economic growth, population growth and other demographic trends, pricing or spatial planning policy are some of those factors. 
Table 6: $\quad$ Three axes of high speed train network in development.

\begin{tabular}{|c|c|c|c|}
\hline & Lisbon/Madrid & Lisbon $/$ Porto & Porto/Vigo \\
\hline Total length & $640 \mathrm{~km}$ & $292 \mathrm{~km}$ & $125 \mathrm{~km}$ \\
\hline Portuguese length & $203 \mathrm{~km}$ & $292 \mathrm{~km}$ & $100 \mathrm{~km}$ \\
\hline Investment & $2400 \mathrm{M}$ & $4500 \mathrm{M}$ & $1400 \mathrm{M}$ \\
\hline Speed & $350 \mathrm{~km} / \mathrm{h}$ & $300 \mathrm{~km} / \mathrm{h}$ & $250 \mathrm{~km} / \mathrm{h}$ \\
\hline Projected demand & $9.4 \mathrm{Mpax}$ & $12.2 \mathrm{Mpax}$ & $3.7 \mathrm{Mpax}$ \\
\hline Average length between stops & $101.5 \mathrm{~km}$ & $73 \mathrm{~km}$ & $33 \mathrm{~km}$ \\
\hline
\end{tabular}

Table 7: $\quad$ Lisbon/Madrid RAVE data.

\begin{tabular}{|c|c|c|c|}
\hline & Lisbon/Madrid & & $\begin{array}{c}\text { High-speed train } \\
\text { displacements }\end{array}$ \\
$\begin{array}{c}\text { Estimated } \\
\text { Total } \\
\text { displacements }\end{array}$ & $23.9 \mathrm{M}$ & & $6.7 \mathrm{M}$ \\
\cline { 1 - 2 } $\begin{array}{c}\text { Estimated } \\
\text { Direct } \\
\text { displacements }\end{array}$ & $1.6 \mathrm{M}$ & \\
\hline $\begin{array}{c}\text { Corridor } \\
\text { Modular } \\
\text { Distribution }\end{array}$ & Year 2003 & Year 2015 & \\
\hline Plane & $956,000(4 \%)$ & $1.01 \mathrm{M}$ \\
\hline Rail & $478,000(2 \%)$ & $6,700,000(21 \%)$ & \\
\hline Private Car & $20,793,000(87 \%)$ & $22,738,460(71 \%)$ & \\
\hline Bus & $1,673,000(7 \%)$ & $1,281,040(4 \%)$ & \\
\hline
\end{tabular}

Three axes must be analysed separately. For the Lisbon/Madrid connection, existing studies are clear. According to the High-speed train studies coordination company (RAVE) [10] it is impossible assure profitability of investment considering the huge costs, however, considering operation and infrastructure management it is possible to achieve a positive financial rentable operation.

According to GPERI [2], in 2008, total displacements with origin/destination in Spain to Portuguese airports were around $2.8 \mathrm{M}$ passengers. From those, around $1.36 \mathrm{M}$ were to Lisbon airport, with $50 \%$ corresponding to direct flights between Lisbon and Madrid (682,000 pax). 2003 data refers to 483,983 passengers between both capitals representing an average growth of $11 \%$ year. This indicates that demand estimations could, in fact, be higher than presented.

The current project design, for this axe, is closely associated with the new international airport location. Current design estimates a new bridge construction on Tagos River. According to RAVE [11], the total investment cost for new bridge construction is over $1700 \mathrm{M}$. In fact, a potential design, with an exit of Lisbon to the North, without such bridge construction would potentially turn the total investment profitable. This could implicate the new airport relocation. This 
solution would also reduce costs of line construction because of potentially common parts between axes. The Sines Port rail connection to Spain could be constructed with a conventional rail design and with reduced costs.

For the Lisbon/Porto axe, according to RAVE [12], it is not profitable in terms infrastructure management costs and operation revenues, as similar projects with such initial investment, however it presents a $3000 \mathrm{M}$ profit for society with the inclusion of external effects such as: Employment, Time Wins, Accidents, Environmental externalities and so on. These effects could be maximized with the Lisbon/Madrid axe project redesign and new international airport relocation.

The Porto/Vigo axe, according to RAVE [13], project presents an Economic VAL (value created to the society by the project) negative. In fact this is affected by an undervalued estimated demand. RAVE study [14] does not explore some crucial aspects: potential demand between Galicia and Porto southern cities, potential demand between Porto southern cities and Porto Airport, potential demand between Porto southern cities and Braga and Viana do Castelo districts and generated demand of a Braga District conventional rail network. Estimations conclude that these aspects could have a positive impact on demand between $30 \%$ and $50 \%$, turning Economic VAL.

\section{A transport theoretical model for Portugal}

\subsection{Anatomic transport model}

Portugal should adopt a transport model, for passengers and logistics, based on some human body systems principals.

Future work will include expanded conceptualization, however a first proposal is included in table 8 .

Table 8: $\quad$ Anatomic systems/transport model.

\begin{tabular}{|c|c|}
\hline Anatomic Systems & Transports mode \\
\hline Skeletal & High-speed train network \\
\hline Muscular & Inter-urban Bus network \\
\hline Digestive/Urinary & Ports network \\
\hline Respiratory & Airport networks \\
\hline Macro circulatory & Conventional rail network/Underground \\
\hline Microcirculatory & Private Car/Trucks/Urban Bus network \\
\hline
\end{tabular}

\section{Proposals}

Transport planning in Portugal should be organized on 3 levels. Level 1 would be the local transport authorities, responsible for regional transport planning at urban and inter-urban planning level and responsible for the mobility of a population no smaller than 1,000,000. Level 2 would be the regional transport authorities, connecting local transport authorities and responsible for the 
mobility of a population no smaller than 3,000,000 and connection between national and local transport projects. Level 3 would be the national transport authority, responsible for the development and management of national transport projects.

The second step would be to synthesize and stabilize the decision process of transport projects. From local to national level projects, the criteria should be normalized and more technical/economical. The viability of passenger transport systems depends on this according to the existing debt levels of transport companies.

\section{Conclusion}

This paper pretends to be a no constraints analysis of some aspects of Portuguese transport strategy. The 2009 general election was a decisive time in terms of transport infrastructure discussion.

For the two projects analysed, conclusions are simple. It is important for the country to structure its development in modern transport infrastructure; however some points, presented during the paper, should receive closer analysis.

The anatomic transport model is a concept that should be developed and conceptualized.

Transport planning and policy making in Portugal certainly has lots of aspects to improve.

\section{References}

[1] Sieber, R.T., Remembering Vasco da Gama: Contested histories and cultural politics of contemporary nation-building in Lisbon, Portugal. Identities-global studies in culture and power, vol. 8, issue 4, pp. 549-581, Taylor \& Francis Ltd, 2001.

[2] Gabinete de Planeamento Estratégico e Relações Internacionais, Boletim Conjuntural Aéreo - Tráfego aéreo comercial nos aeroportos nacionais, MOPTC, Portugal, 2009.

[3] Gabinete de Planeamento Estratégico e Relações Internacionais, Boletim de Conjuntura do modo ferroviário, MOPTC, Portugal, 2009.

[4] Gabinete de Planeamento Estratégico e Relações Internacionais, Boletim Marítimo, MOPTC, Portugal, 2008.

[5] Church, A., Frost, M., Sullivan, K., Transport and social exclusion in London. Transport Policy 7, pp. 195-205, Elsevier Science Ltd., 2000

[6] Deakin, E., Sustainable Development and Sustainable Transportation: Strategies for Economic Prosperity, Environmental Quality, and Equity. Working paper 2001-03, University of California at Berkeley, Institute of Urban and Regional Development.

[7] Wijnen, R.A.A, Walker, W.E., Kwakkel, J. H., Decision support for airport strategic planning, Transportation Planning and Technology, Volume 31, Issue 1, pp. 11-34, 2008 
[8] LNEC, Estudo para análise técnica comparada das alternativas de localização do novo aeroporto de Lisboa na zona da Ota e na zona do Campo de tiro de Alcochete, $2^{\mathrm{a}}$ fase - Avaliação comparada das duas localizações, 2008

[9] Direcção-Geral de Energia e Transportes, Comissão Europeia, Mobilidade Sustentável para o nosso Continente, Manter a Europa em Movimento, Serviços das Publicações oficiais das Comunidades Europeias, 2006

[10] Rede Ferroviária de Alta Velocidade SA, Actualización del modelo de rentabilidad socioeconómico de la alternativa Sur del Tajo. AVEP Inversion Actualizada, 2008

[11] RAVE, Análise custo-benifício ao projecto da Terceira Travessia do Tejo, Relatório Final, 2009

[12] RAVE, Análise custo-benifício da ligação de Alta Velocidade Ferroviária entre Lisboa e Porto, Relatório Final, 2009

[13] A.E.I.E, AVEP, GIF, RAVE, Estudio de Viabilidad técnica, económica y medioambietal de la conexión Hispano-Lusa en Alta Velocidad VigoOporto Demanda Actual y prognósis, Capítulo 13 Plan de explotación y análysis de rentabilidad, 2004

[14] A.E.I.E, AVEP, GIF, RAVE, Estudio de Viabilidad técnica, económica y medioambietal de la conexión Hispano-Lusa en Alta Velocidad VigoOporto Demanda Actual y prognósis, Capítulo 10 Análysis e Caracterizacion de la demanda actual de transporte, 2004 